\title{
A STUDY OF RETROMOLAR FORAMEN/CANAL IN NORTH INDIAN
} POPULATION

\section{Sadiq Siddiqui ${ }^{* 1}$, Syed Zaidi ${ }^{2}$, Sandeep Arora ${ }^{3}$.}

${ }^{{ }^{*} 1}$ Assistant professor, Dept. of anatomy, Rajshree medical research institute, Bareilly (up), India.

2 Professor \& Head, Dept. of anatomy, T.S. Mishra medical college \& hospital, Lucknow (UP), India.

${ }^{3}$ Associate Professor, Dept. of anatomy, Rajshree medical research institute, Bareilly (up), India.

\section{ABSTRACT}

The Retromolar foramen/canal are one of the non-metric variants of the mandible located in the retromolar fossa of the mandible behind the $3^{\text {rd }}$ molar of mandible. These are obviously of profound dental and surgical importance. The aim of the study was to know the prevalence of retromolar canal/foramen in north Indian population. In the present study, 35 dry mandibles of unknown sex of north Indian origin were examined by naked eyes to know the incidence of retromolar foramen/canal. The retromolar foramen/canal was found in 6 mandibles (17.14\%), bilaterally in 2 mandibles and unilaterally in 4 mandibles. We conclude that retromolar foramen /canal is of profound clinical importance.

KEY WORDS: Retromolar foramen, Retromolar canal, Mandibular variants \& Mandibular anomalies.

Address for Correspondence: Sadiq Siddiqui, Assistant professor, Dept. of anatomy, Rajshree medical research institute, Bareilly (up), India. E-Mail: drsadiqsiddiqui@gmail.com

Access this Article online

Quick Response code

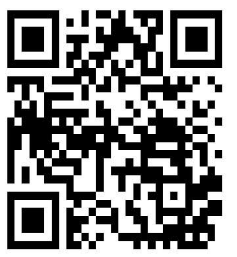

DOI: $10.16965 /$ ijar.2018.312

Journal Information

International Journal of Anatomy and Research

ICV for 2016 ISSN (E) 2321-4287 | ISSN (P) 2321-8967

https://www.ijmhr.org/ijar.htm

DOI-Prefix: https://dx.doi.org/10.16965/ijar

Article Information

Received: 07 Jul 2018

Peer Review: 09 Jul 2018

Revised: None
Accepted: 13 Aug 2018

Published (O): 05 Sep 2018

Published (P): 05 Sep 2018

\section{INTRODUCTION}

The Retromolar fossa is a triangular area posterior to 3rd mandibular tooth [1]. An opening called retromolar foramen is known to be present in this area [2]. This foramen transmits neurovascular structures that contribute to nutrition and innervations of the pulp and peri-odontium molar teeth [3]. Although the presence of this foramen is acknowledged [4], some anatomy textbooks do not mention its occurrence or anatomical details. Some authors reported that the incidence of retromolar foramen does not show differences as regards to their side or sex $[5,6]$. The foramen extends as a retromolar canal into the body of mandible [7]. When present, this canal is known to transmit neurovascular bundle and hence it is extremely important in surgical procedures that involve the mandible. Narayana studied retromolar canal in south Indian dry mandibles [8].

Ossenberg emphasised that retromolar foramen is an important anatomical landmark and suggested that foramen varies according to ethnic factors [2].

It is important for the practising surgeons to know these variations in the incidence of retromolar foramen/canal, which also vary on the racial and regional basis, and has been neglected and not mentioned in all textbooks. On this background, present study is done to note the prevalence of retromolar foramen/ canal in north Indian population. 


\section{MATERIALS AND METHODS}

In the present study, 35 dry adult human mandibles of unknown sex of north Indian origin were examined. Only those mandibles were selected which were free from any deformity or fracture. Present study was carried out in the department of anatomy, Rajshree medical research institute, Bareilly, Uttar Pradesh, India. In each of the selected mandibles, area behind the $3^{\text {rd }}$ molar tooth was examined meticulously by naked eyes to note the presence of retromolar foramen/canal and photographed by Sony DSLR.

\section{OBSERVATIONS}

The retromolar foramen/canal was found to be present in 6 mandibles (17.14\%), bilaterally in 2 mandibles (5.71\%) and unilaterally in 4 mandibles (11.42\%). Out of 4 mandibles, which had unilateral retromolar foramen, 2 mandibles (5.71\%) had retromolar foramen on right side and 2 mandibles (5.71\%) on left side (Table1). Figure 1 shows the presence of retromolar foramen bilaterally and Figure 2 shows the unilateral retromolar foramen.

Table 1: Distribution of Retromolar foramen /canal.

\begin{tabular}{|c|c|c|c|}
\hline & Right & Left & Bilateral \\
\hline No. Of mandibles & 2 & 2 & 2 \\
\hline Percentage (\%) & $5.71 \%$ & $5.71 \%$ & $5.71 \%$ \\
\hline
\end{tabular}

Table 2: Comparative study of incidence of Retromolar foramen /canal.

\begin{tabular}{|c|c|c|}
\hline Workers & Global region & Percentage (\%) \\
\hline Kodera H \& Hashimoto I, 1995 & Japanese & $19.50 \%$ \\
\hline Suazo et al. 2008 & Brazilian & $12.90 \%$ \\
\hline Narayana et al.2002 & South Indian & $21.90 \%$ \\
\hline Sadiq, Zaidi \& Arora & North Indian & $17.14 \%$ \\
\hline
\end{tabular}

Fig. 1: bilateral retromolar foramen/canal.

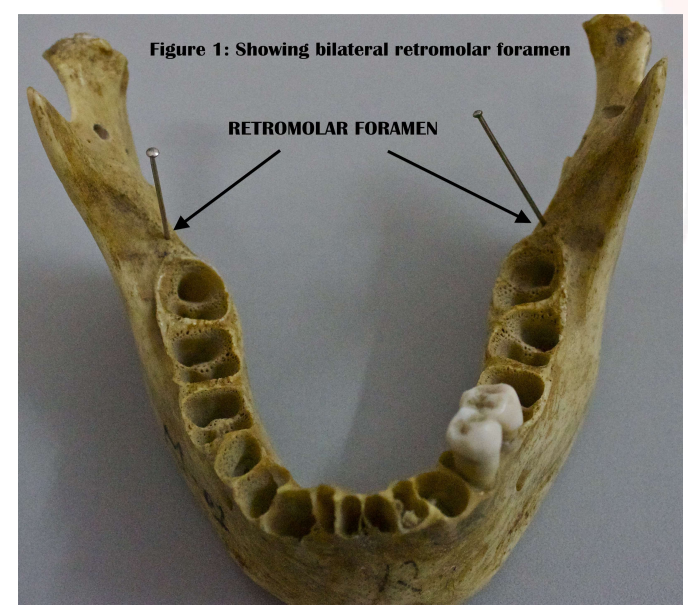

Fig 2: unilateral retromolar foramen/canal.

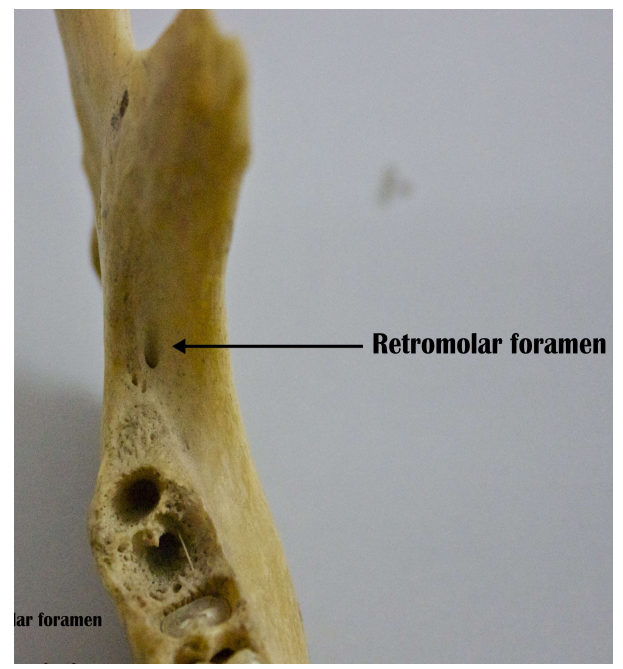

\section{DISCUSSION}

Retromolar foramen/canal is located in the retromolar fossa, which is considered as an anatomical variation. However in our north Indian population sample, we detected retromolar foramen in $17.14 \%$ which was higher than that reported by Suazo et al (2008), $12.9 \%$ in Brazilian [9], and Sawyer et al (1991), 7.7\% in Americans [6], but lower than that reported by Narayana et al (2002) was 21.9\% [8], and Senthil et al (2010) was $17.3 \%$ [10] in south Indian population.

Suazo et al (2008) studied the incidence of retromolar foramen in Brazilian population to be $12.9 \%$ [9], lower than what was reported by Kodera et al (1995) who detected it to be $19.5 \%$ in Japanese population sample [7].

Narayana et al (2002) in his south Indian population sample detected this incidence to be $21.9 \%, 10.7 \%$ of these were found to be on right side $\& 7.1 \%$ on left side. Retromolar foramen was found to be $4.1 \%$ bilaterally in their study [8].

Ossenberg stated that retromolar foramen is more frequent unilaterally than bilateral in mandibles of Latin America such as Argentina, Colombia, and Brazil [2] which was consistent with the finding of our study which showed that retromolar foramen is more frequent unilaterally $(11.42 \%)$ than bilateral $(5.71 \%)$ in north Indian population.

The presence of retromolar foramen/canal and its contents have great clinical significance in surgical procedures performed in retromolar 
area, as these contain neurovascular bundle supplying the lower $3^{\text {rd }}$ molar and neighbouring regions. These might be injured in dieresis procedures, flap lifting, bone tissue for autologous bone grafts, osteotomy for the surgical extraction of lower $3^{\text {rd }}$ molars, placement of osseointegrated implants for orthodontic or in sagittal split osteotomy surgery [11].

Schejtman et al. (1967) mentioned that the neurovascular bundle passing through the retromolar foramen/canal are mainly distributed in the tendon of temporalis \& buccinator muscles, in the region of alveolar process and in the mandibular 3rd molar [12].

Azaz and Lustmann (1973) mentioned that the possible vascular excessive bleeding or postoperative hematomas could be caused by damage to the neurovascular bundle [13].

In addition to such risks, retromolar foramen/ canal is also considered as potential route for the entry of additional innervation to lower $3^{\text {rd }}$ molar causing failure in anaesthetic mandibular blocking [14].

\section{CONCLUSION}

It is therefore concluded in the present study that this variant of mandibular foramen/canal is of profound clinical importance and the comparison of similar studies (Table-2) is also of considerable regional and racial significances. It also suggests that special care should be taken during routine anaesthetic, surgical and implantation procedure of the mandible so that neurovascular bundle passing through the retromolar foramen/canal should not be damaged.

\section{Conflicts of Interests: None}

\section{REFERENCES}

[1]. Mcminn RMH. Last's anatomy, regional and applied. $8^{\text {th }}$ edition. Churchill Living Stone, Singapore, 1992; pp 669-671.
[2]. Ossenberg, N. S. Retromolar foramen of the human mandible. Am. J. Anat Clin. 1987; 3: 119-127.

[3]. Sicher H. Oral Anatomy. $3^{\text {rd }}$ ed. St. Louis, MO, Mosby, 1960.

[4]. Soams RW. Skeletal system. In: Williams PI, Bannister LH, Berry MM, Collins P, Dyson M, Dussek JE, Ferguson MWJ.Gray's Anatomy, 38th edition. Churchill Livingstone, London, 1995,pp 576-578.

[5]. Hollinshead WH. The Head and Neck. Anatomy for surgeons. $2^{\text {nd }}$ edition. Vol I. Herper and Row Publishers, London, 1968,pp 392-398.

[6]. Sawyers D.R and Kiely M.L. Retromolar foramen. A mandibular variant important to dentistry. Ann Dent.1991; 50: 16-18.

[7]. Kodera $\mathrm{H}$ \& Hashimoto I. A case of mandibular retromolar canal; elements of nerves and arteries in this canal, Kaibogaku Zasshi, 1995; 70:23-30.

[8]. Narayana K, Nayak UA, Ahmed WN, Bhat JG, and Devaiah BA .The retromolar foramen and canal in south Indian dry mandibles, Eur J Anat, 2002; 6(3): 141-146.

[9]. Suazo G I, Zavando MD \& Cantin LM. Retromolar canal and foramenprevalence in dried mandibles and clinical implications, Int.J.Odontostomat, 2008; 2(2): 183-187.

[10]. Senthil Kumar S, Kesavi D. A study on the incidence of Retromolar Foramen and Canal in Indian Dried Human Mandibles and its Clinical Significance. International Journal of Anatomical Sciences. 2010;1: 14-16.

[11]. Reyneke JP, Tsakiris P, \& Becker P. Age as a factor in the complication rate after removal of unerupted/ impacted third molars at the time of mandibular sagittal split osteotomy, J Oral Maxillofac Surg. 2002; 60(6): 654-9.

[12]. Schejtman R, Devoto F C \& Arias NH. The origin and distribution of elements of the human mandibular retromolar canal, Arch Oral Biol, 1967; 12(11): 12618

[13]. Azaz B \& Lustmann J. Anatomical configurations in dry mandibles, Br J Oral Surg, 1973; 11(1): 1-9.

[14]. Boronat LA \& Penarrocha DM. Failure of locoregional anaesthesia in dental practice, Review of the literature, Med Oral Patol Oral Cir Bucal. 2006; 11(6): E 510-3.

How to cite this article:

Sadiq Siddiqui, Syed Zaidi, Sandeep Arora. A STUDY OF RETROMOLAR FORAMEN/ CANAL IN NORTH INDIAN POPULATION. Int J Anat Res 2018;6(3.3):5695-5697. DOI: 10.16965/ijar.2018.312 